UDC 334.724:334.021.1:658.14.011.1

JEL Classification: H70, M11, M12, M13

http://doi.org/10.21272/mmi.2019.3-27

Nataliya Tyukhtenko,

Ph.D, Professor, Kherson State University, Ukraine

Serhii Makarenko,

Ph.D, Kherson State University, Ukraine

Nataliia Oliinyk,

Ph.D, Associate Professor, Kherson National Technical University, Ukraine

Krzysztof Gluc,

D.Sc., Associate Professor, Malopolska School of Public Administration at the University of Economics in Krakow, Poland

Edwin Portugal,

Ph.D, Professor, State University of New York in Potsdam, USA

Serhii Rybachok,

Kherson State University, Ukraine

\title{
INNOVATIVE DEVELOPMENT OF THE REGIONS: COOPERATION BETWEEN ENTERPRISES AND STATE INSTITUTIONS
}

Abstract. In the conditions of limited sources of financing for the introduction of advanced innovative technologies and equipment modernization, to retain the existing positions and increase the overall level of competitiveness can only the company that establishes a close relationship with government bodies, local governments and trade union organizations with the aim of obtaining possible preferences for development within the existing regulatory right field. The purpose of the article is to analyze the main socio-economic indicators of the development of Ukraine and its regions, the definition and justification of possible areas of establishing interaction between private enterprises and government agencies. The methodological basis of the study consisted of scientific works of domestic and foreign scientists and leading specialists, statistical and analytical materials of state authorities. The results are obtained through the use of such methods as expert - to identify the impact of qualitative and quantitative indicators on the socio-economic development of the Kherson region; economics and mathematics - to study the influence of a defined group of indicators on the index of the physical volume of the gross regional product; abstract-logical - for a theoretical synthesis and formulation of conclusions. It is revealed that among the key areas of interaction is the promotion of the state and local authorities in the creation of industrial parks. The conducted research on identifying the strengths and weaknesses, opportunities and threats of the economy of the Kherson region indicates the need to develop measures to ensure the economic security of the region. To solve these problems at the regional level, it is proposed to implement a state policy that would be carried out in the following areas: ensuring a solid institutional protection of investor's property rights; improvement of the legislative framework; establishing an effective mechanism for combating corruption in Ukraine, developing an effective state policy on amnesty and unshadowing of incomes of individuals and legal entities.

Keywords: socio-economic development, management, innovation, industrial park, competitiveness, foreign investment, amnesty of capital.

Introduction. In modern conditions of market economy development, characterized by a rapid increase in the level of competition in the domestic and foreign markets for the supply of raw materials and sales of final products, the growing demands of customers for the consumer characteristics of goods, works, services, only an enterprise that has competitive advantages in all spheres of economic activity can maintain existing positions and ensure economic growth. In the area of saving time, reducing costs, improving quality, ensuring flexibility, introducing innovations, developing knowledge and the like. Each business entity is obliged to represent the prospects and the need for finance, raw materials, labour,

Cite as: Tyukhtenko, N., Makarenko, S., Oliinyk, N., Gluc, K., Portugal, Ed., \& Rybachok S. (2019). Innovative development of the regions: cooperation between enterprises and state institutions. Marketing and Management of Innovations, 3, 354-365. http://doi.org/10.21272/mmi.2019.3-27 

Cooperation Between Enterprises and State Institutions

intellectual resources, production facilities, sources of their receipt, and also be able to efficiently use the available production resources in the course of the operation. In the conditions of limited sources of financing for the introduction of advanced innovative technologies and equipment modernization, to retain the existing positions and increase the overall level of competitiveness can only the company that establishes a close relationship with government bodies, local governments and trade union organizations with the aim of obtaining possible preferences for development within the existing regulatory right field. The indicated determines the relevance of the topic of research, its purpose and content. The purpose of the article is to analyse the main socio-economic indicators of the development of Ukraine and its regions, the definition and justification of possible areas of establishing interaction between private enterprises and government agencies.

Literature Review. A key element of innovative business development is the establishment of interaction and obtaining of a possible direct (in the form of financial resources) and indirect (in the form of tax privileges, allocation of additional budget places for the training of skilled personnel on a state order, etc.) assistance from state and local authorities. Small and medium-sized enterprises are especially sensitive to quality and changes of the business environment (e. g., Veliu et al., 2018; Cepel et al., 2018; Ivanová \& Čepel, 2018; Ključnikov et al., 2017; Adair \& Adaskou, 2018). According to Pavelková et al. (2009). Small and medium-sized enterprises are of great importance for the world economy because they promote competitive dynamics of economic systems and directly or indirectly affect large companies, especially in the fields of efficiency growth and innovations' development (Kozubikova et al., 2019). While considering the factors that shape the quality of the business environment, emphasis should not be placed only on assessing the current conditions for existing firms, as well as on the factors and conditions for starting a new business. For example, Obadić \& Aristovnik (2011) argue that the quality of the education system is a factor in economic growth, and entrepreneurial education can also play an important role in shaping and perceiving the business environment.

The current realities of the Ukrainian economy evidenced significant miscalculations by representatives of the pro-government structures in attracting advanced innovative technologies into business processes and training and retaining skilled professionals in domestic business structures. This is confirmed by the materials published by the World Economic Forum on the World Economic Ranking by the Global Competitiveness Index 2017-2018 (Economic Discussion Club, 2018). Thus, despite the improvement of the position on four points, Ukraine ranked 81st place among 137 countries of the world. Most were lost due to the "Labour Market Efficiency" component, which made Ukraine receive the 86th place, having lost 13 points in comparison with 2016-2017 and 30 points in comparison with 2015-2016. Two points were also lost for the component, which characterizes higher education and professional training. Despite the relatively high levels of "higher education and training" (35th place in 2017-2018 among 137 countries of the world), the quality of management schools is very low (88th place), as well as the level of staff training in the workplace (88th place). Ukraine also ranked 51st in terms of primary education. And this is even though Ukraine is 25 th in the presence of scientists and engineers.

The above analysis shows that in spite of the relatively large number of scientists and engineers, in Ukraine there is a low quality of research institutes (60th place) and the ability to innovate (51st place), which is confirmed not only by the lack of cooperation between state and local authorities, universities and business representatives in research and development (73th place), low costs of companies for research and development (76th place) and government procurement of high-tech products (96th place), but also the actual impossibility to retain and attract talents in economic activities (in accordance with 129th and 106th places). The results of previous studies (Soloviova et al., 2016) also indicate that the methods of assessing the level of socio-economic development of administrative-territorial units are inadequate at the state level, and as a result, the lack of opportunities to build an effective forecasting model and formulate a clear and well-grounded plan for the further development of problem areas, to ensure effective mutually 
agreed development of the economic and social sphere, to improve the quality of life of the population. So, during the economic and mathematical analysis it was revealed that from the proposed set of indicators, which accounted for 81 items in 10 areas of analysis (in accordance with the Decrees of the Cabinet of Ministers of Ukraine dated June 9, 2011 No. 650 and April 9, 2012 No. 335) only 13 indicators had a significant impact on the level of socio-economic development of the country as a whole and of a particular region. The highest correlation was observed between the gross domestic product (effective factor) and the volume of realized industrial output per unit of population $(r=0.9922)$, the volume of agricultural production per 100 hectares of agricultural land $(r=0.865)$, the volume of capital investments (except for investments from the state budget) per unit of population $(r=0.9914)$, the volume of tax revenues to local budgets per unit of population $(r=0.996)$, the volume of commissioned housing per 10 thousand population $(r=0.97)$. These indicators reflected the existing system of interconnection between the population (labour resources), business entities of all forms of ownership and state institutions.

Methodology and research methods. The methodological basis of the study consisted of scientific works of domestic and foreign scientists and leading specialists, statistical and analytical materials of state authorities. As a method of data collection for the research was chosen a questionnaire. The questionnaire research was carried out in selected higher education institutions (Kherson State University), local authorities (Department of Economic Development and Trade of Kherson Regional State Administration; Main Department of the State Fiscal Service of Ukraine in Kherson region, Autonomous Republic of Crimea and Sevastopol), trade union organizations (Kherson regional inter-branch council of trade unions), leading enterprises of Kherson city ("Amalteya" LLC, "Leather Plant" Platan LTD "Ltd.) and public organizations (Business Association "MI-KHERSONTS"). The results are obtained through the use of such methods as expert - to identify the impact of qualitative and quantitative indicators on the socio-economic development of the Kherson region; economics and mathematics - to study the influence of a defined group of indicators on the index of the physical volume of the gross regional product; correlation-regression analysis - to find out the relationship between the productive factor and the identified factors; SWOTanalysis - for identifies the strengths and weaknesses, opportunities and threats of the Kherson region; abstract-logical - for a theoretical synthesis and formulation of conclusions, for identifies key areas of interaction between business and government. Given that each expert has a different level of education, experience, the scale of management activity, the coefficient of expert competence was determined using a methodological approach developed in previous studies (Tyukhtenko \& Makarenko, 2016). The abovementioned allowed considering the individual level of practical and scientific training of each of the respondents and reducing the level of error when using the intuitive group of methods.

It is also necessary to take into account that the presence of a wide range of indicators during the evaluation can lead to a decrease in the share of the most influential factors, increase the probability of error in estimating and forecasting and lead local authorities and local government bodies to implement a set of measures to improve the values of indicators that are not significant for the region. Therefore, according to the views of the experts involved, the following indicators have the greatest influence on the socio-economic development of the region: real disposable income of the population, in $\%$ to the corresponding period of the previous year, $X_{1}$ (the results of the survey -9.3 of 10 points); capital investment index, in\% against the corresponding period of the previous year, $X_{2}(9.2)$; the rate of growth of direct foreign investments in the economy of the region, in $\%$ to the previous year, $X_{3}(8.5)$; index of industrial production, in\% to the previous year, $X_{4}(9.8)$; index of agricultural products, in $\%$ to the previous year, $X_{5}(9.6)$; the share of industrial enterprises engaged in innovations, $X_{6}$ (8.7); economically active population aged 15-70, thousand people, $X_{7}(7.9)$. A productive factor by which one can determine the level of fluctuations in the development of a region was taken as an index of the physical volume of the gross regional product (in prices of the previous year), $Y(9.4)$. 
N. Tyukhtenko, S. Makarenko, N. Oliinyk, K. Gluc, Ed. Portugal, S. Rybachok. Innovative Development of the Regions: Cooperation Between Enterprises and State Institutions

Using the formula for calculating the pair correlation coefficients, the following relationship was established between the performance indicator $(Y)$ and the factors indicated:

- $r_{y \times 1}=0.4547$ - by the scale of the assessment of the relationship of variables, the relationship between $Y$ and $X_{1}$ is considered average;

- $r_{y \times 2}=0.6258$ - the connection between $Y$ and $X_{2}$ is considered higher than average;

- $r_{y \times 3}=0.4314$ - the connection between $Y$ and $X_{3}$ is considered average;

- $r_{y \times 4}=0.0843$ - the connection between $Y$ and $X_{4}$ is almost absent;

- $r_{y \times 5}=0.7397$ - the connection between $Y$ and $X_{5}$ is considered higher than average;

- $r_{y \times 6}=-0.1377$ - the connection between $Y$ and $X_{6}$ is almost absent;

- $r_{y \times 7}=0.2557$ - the connection between $Y$ and $X_{7}$ is considered lower than the average.

The existing contradictions regarding the results obtained, especially in terms of determining the relationship between the performance index $(Y)$ and the index of industrial products $\left(\mathrm{X}_{4}\right)$, are associated with constant changes in the analysis methods conducted by the state statistical bodies. Thus, in 2007, the results of the industrial activity of one of the most powerful light industry enterprises of Ukraine and Europe in general, the budget-forming company of Kherson - Kherson Cotton Plant, were isolated from the basis of calculations, in which the number of employees in the heyday reached 23 thousand people. As a result, instead of reducing the volumes of industrial products by the results of 2007, an increase of $9.4 \%$ was received. The fall of volumes of production of the light industry by enterprises of the Kherson region during 1990-2016 has reached catastrophic volumes, namely, in 2016 more than 250 times the volume of production decreased compared to 1990, and 15.6 times compared to 2008.

Also, one of the conditions for the expediency of using this group of factors in further research is to verify the presence of multicollinearity. Using the formula to check the presence of multicollinearity between the factors, only a significant link was found between the indicator $\mathrm{X}_{1}$ (real disposable income of the population, in $\%$ to the corresponding period of the previous year) and $X_{3}$ (the rate of growth of direct foreign investments in the economy of the region, in $\%$ to the previous year) $\left(r_{\times 1 \times 3}=0.755\right)$. This is since in the conditions of the devaluation of the national currency the calculation of the minimum allowable wage in foreign currency allowed the population of the region to receive decent wages compared with its average size on domestic economic entities. There is almost no relationship between indices of industrial products and agricultural products. This may indicate a low level of unreliability of existing statistical indicators, which, in turn, does not allow foreign investors to determine the real state of economic development of a region and the expediency of investment in the proposed projects for the processing of agricultural products. Also, the indicated circumstance can testify to the use of the agricultural potential of the Kherson region and Ukraine in general only as a raw material appendage for production processes in the economically developed regions of the neighbouring countries. Thus, according to the results of 2017, the largest share in the structure of exports of goods of the region is occupied by organic products $(36.7 \%)$, which during the reporting year were exported to the amount of more than 106 million US dollars, an increase compared to 2016 was $9.6 \%$.

The introduction of a sound methodological approach to assessing the level of socio-economic development of the country and regions in particular will allow not only to identify problem areas in the development of the respective territories, but also to obtain to the potential investor reliable information about the real state of affairs and to determine the validity of further investments in the activities of the object of study. The interest of foreign investors in investing in industrial enterprises, including light ones, and the creation of a production process in the country can be expressed by the following dependence (the cost of equipment maintenance, rental of premises, insurance and other non-production costs will be considered the same both in Ukraine and in the territory of a foreign enterprise): 
where $\mathrm{WF}_{\mathrm{a}}$ - the wage fund required for manufacturing products abroad; WFu - the wage fund required for the manufacture of products in Ukraine; a - percentage of materials remaining at the disposal of the enterprise (in accordance with the concluded agreements); $\mathrm{M}_{\mathrm{e}}$ - amount of material expenses; $\mathrm{b}$ additional percentage of expenses related to transportation, insurance of raw materials, materials and final products, passing the necessary customs procedures; $T_{e}$ - amount of transport, insurance and customs expenses; $\mathrm{c}$ - the reserve ratio of the protection of the foreign investor's capital in conditions of political and economic instability.

While the inequality in formula (1) will be fulfilled, industrial enterprises of the region will be able to operate efficiently on the terms of toll manufacturing and overcome the financial crisis without losing competitive positions both on the domestic and foreign markets. To maximize the probability of attracting domestic and foreign investments, it is necessary to ensure that equal income is obtained on equal terms. By the said the capital, in whatever it is enclosed, must bring the owner the same profit as the capital enclosed into another business. These provisions provide the basis for the following conclusion: money invested at different times, in different components of capital, in different places must be equally profitable, that is, inequality must be fulfilled:

By any option:

$$
\frac{P_{i}(t)}{(1+r)^{t}}-\frac{P_{i}(g)}{(1+r)^{g}} \geq 0
$$

$$
P d_{i}(t)=P d_{j}(g) \times k_{s} \times k_{p}
$$

where $P_{i}(t)$ i $P_{j}(g)$ - the amount of income received from investments in factors of production (for example, in the modernization of production capacity) $i$ and $j$ in the period of time $t$ and $g ; r$ - loan interest rate (discount rate); $P \mathrm{~d}_{\mathrm{i}}(\mathrm{t})$ i $\mathrm{Pd}_{\mathrm{j}}(\mathrm{g})$ - amount of investments into production factors $i$ and $j$ in the period of time $t$ and $g ; k_{s}, k_{p}$ - coefficients that lead to the comparable appearance of qualitatively different factors of production; $\mathrm{t}$ and $\mathrm{g}$ - period of time.

These factors lead to different enclosures in a comparable view of the quality of resources and their remoteness from the place of consumption.

It is also necessary to consider that the introduction of innovations will allow not only to generate profit but also to reduce the level of losses of raw materials and improve the quality of products manufactured at the enterprise.

For the effective functioning of industrial enterprises and the implementation of measures for the purchase of innovative specialized equipment, it is necessary to ensure that the following system of conditions is met:

$$
\left\{\begin{array}{c}
D_{d}+N_{p}>\left(L_{b}+D_{a}\right) \times\left(1+C_{p r}\right) \\
N_{p}>0
\end{array},\right.
$$

where $D_{d}$ - the number of depreciation deductions; $N_{p}$ - net profit; $L_{b}, D_{a}$ - annual (quarterly, monthly) corresponding pay "body" for the loan and the number of dividends; $\mathrm{C}_{\mathrm{pr}}$ - coefficient of protection.

Results. To ensure the growth of the revenue part of budgets of all levels, state and local authorities should create appropriate conditions for the organization of the full cycle of finished goods production at 

Cooperation Between Enterprises and State Institutions

domestic enterprises. This can be manifested in the form of providing additional privileges for the purchase of innovative equipment that is not produced in the country, the attraction of foreign capital to the development of leading enterprises of the processing industry. Thus, in accordance with Article 18 of Section IV of the Law of Ukraine "On the regime of foreign investment" (before the adoption of the Law of Ukraine "On amendments to certain legislative acts of Ukraine in connection with the adoption of the Customs Code of Ukraine" of March 13, 2012, No. 4496-VI) it was assumed that property imported into Ukraine as a contribution of a foreign investor to the statutory fund of enterprises with foreign investments (except for goods for sale or own consumption), is exempted from the duty (in case of observance of established procedures). Using the above legal norm, industrial enterprises, including light ones, could not only reduce the proportion of labour costs by permanently introducing innovative specialized equipment into production, but also to interest a foreign investor in productive cooperation in order to increase production volumes, introduce innovative technologies, and produce new types of products that are competitive in both domestic and international sales markets.

In modern business conditions, similar preferences for domestic business entities in the procurement of foreign innovation equipment and its implementation in the production process remained only on condition of the establishment of industrial parks. Thus, according to Section X of the Law of Ukraine "On Industrial Parks" and Article 287, paragraph 6, of the Customs Code of Ukraine stipulates, that when imported into the customs territory of Ukraine from customs duty the following shall be exempted: equipment and components thereof, materials which are not manufactured in Ukraine and which are not excisable goods and are imported by the initiators of the creation of industrial parks such as: business entities, managing companies of industrial parks involved in the arrangement of industrial parks; equipment and components to them which are not produced in Ukraine and are not excisable goods imported by the participants of industrial parks for the business activity within the industrial parks. At the same time, the released funds should be used by the relevant subjects for arranging industrial parks, including using the latest, energy-saving technologies; the introduction of the latest technologies related to the economic activity within the industrial parks; increase of output and reduction of expenses by types of economic activity, provided by this Law, within industrial parks; realization of research activity within the industrial parks; repayment of loans and payment of other borrowings used for the construction of industrial parks and the implementation within them of economic activities, as well as for the payment of interest on such loans and borrowings.

In conditions of a low level of competitiveness of the Kherson region in the overall All-Ukrainian rating - 21 out of 25 places in January-October 2018 (Research Center for Industrial Development Problems of the National Academy of Sciences of Ukraine, 2018), a key component for improving the overall state of development of the region is the establishment of close cooperation of state institutions with business entities to create new jobs with decent wages, growth in production and revenues of taxes and fees to budgets of all levels.

Considering that light industry is one of the most important sectors of non-food production, which provides fabrics, clothing, footwear, has the closest ties with agriculture and the chemical industry - the main suppliers of raw materials for the industry, as well as mechanical engineering, it is advisable to consider the possibility of creating an industrial park on the platform of Kherson Cotton Plant. Given that in $2011,51.76 \%$ of the shares of Kherson Cotton Plant were returned to the state's ownership, the bodies of state and local authorities, which exercise the owner's right to land on behalf of the Ukrainian people, have the right to create the said industrial park. When choosing the management company of the industrial park it is necessary to consider the peculiarities of its development and the branching of foreign economic relations, the existence of a complete cycle of production and the introduction of advanced innovative technologies into the production and management of labour resources. In addition to providing possible exemptions for the import of foreign equipment that is not produced on the territory of Ukraine, it is also 

Cooperation Between Enterprises and State Institutions

necessary to create appropriate conditions for attracting foreign investors. Table 1 identifies the strengths and weaknesses, opportunities and threats of the Kherson region using a SWOT analysis of the investment component of the region.

Table 1. SWOT-analysis of the investment component of the Kherson region

\begin{tabular}{|c|c|}
\hline Strengths & Weaknesses \\
\hline $\begin{array}{l}\text { - the favourable geographical location } \\
\text { of the region with access to the Dnipro } \\
\text { River and the Black and Azov Seas; } \\
\text { - } \quad \text { favourable climatic conditions; } \\
\text { - } \quad \text { environmentally friendly region; } \\
\text { - } \quad \text { developed infrastructure: sea and } \\
\text { river ports, airport; } \\
\text { - } \quad \text { developed trade and services sector; } \\
\text { - } \quad \text { competitive labour cost; } \\
\text { - } \quad \text { cultural and historical heritage }\end{array}$ & $\begin{array}{l}\text { - } \text { the imperfection of the legislative base; } \\
\text { - } \text { the inability of the judiciary to protect the property } \\
\text { rights of investors; } \\
\text { - } \text { negative investment image; } \\
\text { - lack of mechanisms for insurance of investment } \\
\text { risks; } \\
\text { - instability of the tax system; } \\
\text { - } \quad \text { territorial location of the area along with the } \\
\text { temporarily occupied territory of the Autonomous } \\
\text { Republic of Crimea; } \\
\text { - corruption; } \\
\text { - bureaucracy; } \\
\text { - low industry development; } \\
\text { - bad road conditions }\end{array}$ \\
\hline Opportunities & Threats \\
\hline $\begin{array}{l}\text { - promotion of the region, holding of } \\
\text { international investment forums; } \\
\text { - Involvement of investors in cooperation; } \\
\text { - development of the agricultural sector; } \\
\text { - development of the processing industry; } \\
\text { - alternative energy development }\end{array}$ & $\begin{array}{l}\text { - political instability; } \\
\text { - the economic crisis in the country; } \\
\text { - the complexity of predictability of the level of inflation } \\
\text { due to the instability of the economy; } \\
\text { - a shortage of domestic resources for investing; } \\
\text { - high-interest rates on a loan }\end{array}$ \\
\hline
\end{tabular}

We agree with the opinion of Malay A. O. (2011) that the main reason for failures in attracting foreign investment is that Ukraine still does not have a systematic policy on the formation of an investment climate. This concerns the imperfection of regional policy aimed at ensuring the investment component of the region to implement international projects. There are also complications in determining the level of competitiveness and assessing the feasibility of investing in the development of domestic industrial enterprises. Considering the formulas 1, 2, 4 in Figure 1, we will illustrate a block diagram of the interest of foreign investors in creating a production process on the territory of Ukraine and the Kherson region.

It is also necessary to take into account that the permanent development and implementation of a set of measures to improve the management of time resources in production is one of the main directions of increasing the profitability of economic activity due to the growth of labour productivity, more efficient use of existing production assets and minimization of fixed costs per unit of output. Optimizing the time load and defining its limit for employees of the enterprise, while ensuring the implementation of production standards per hour, will not only reduce the level of injury (social effect), shortage and waste in the production of goods (economic effect), but also will contribute to obtaining greater satisfaction from the work performed, the normalization of the psychological climate in the team, which, as a consequence, can lead to an increase in the level of productivity. When determining the optimal time load for employees, it is necessary to consider possible variations in the size of marginal labour productivity and labour costs. 
N. Tyukhtenko, S. Makarenko, N. Oliinyk, K. Gluc, Ed. Portugal, S. Rybachok. Innovative Development of the Regions: Cooperation Between Enterprises and State Institutions

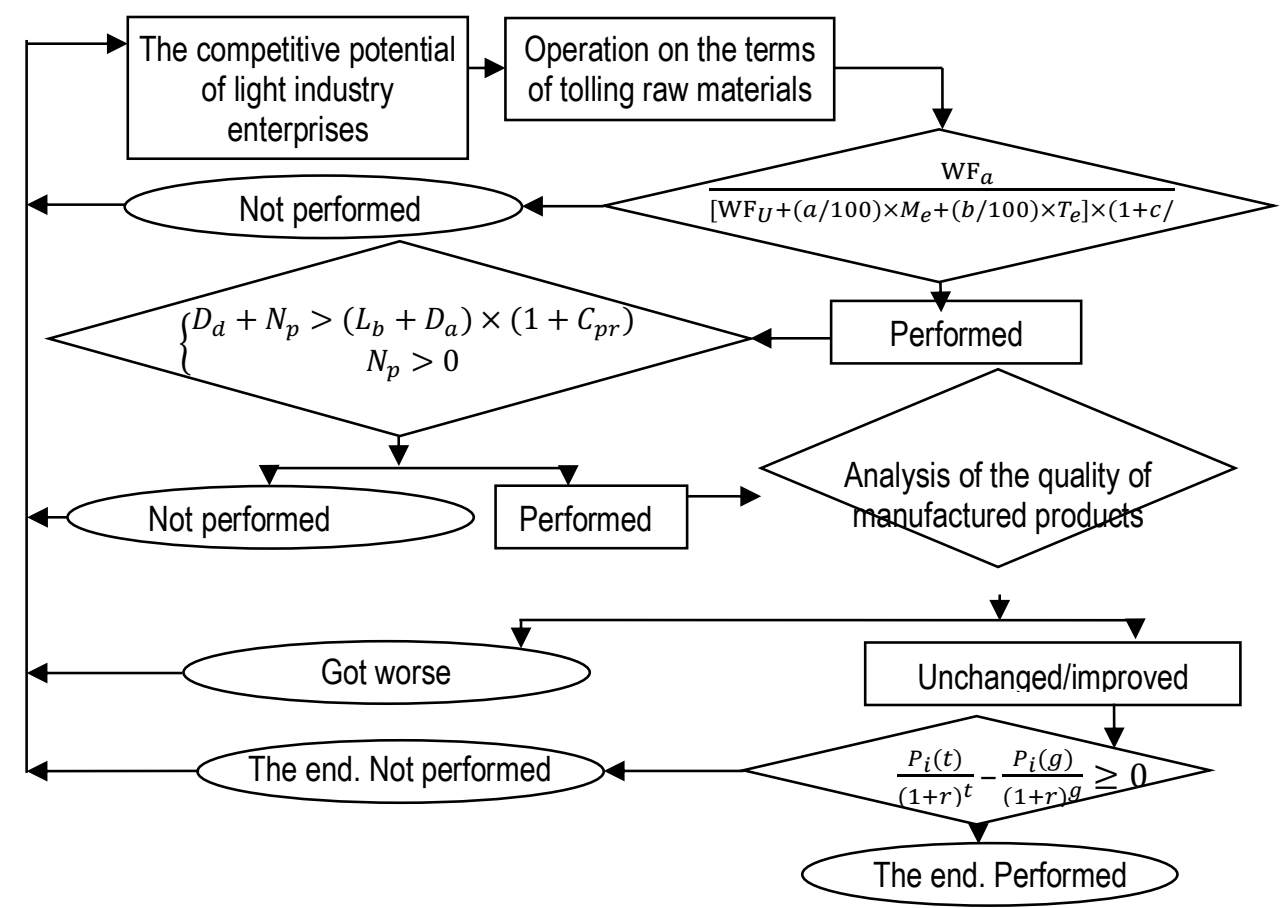

Figure. 1. Block diagram of interest of foreign investors in the creation of the production process in the country

Source: developed by the authors.

Table 2 shows the mechanism of determining the optimal time load on the example of the leading employee of the production site for sewing products.

Table 2. An example of determining the optimal workload for employees

\begin{tabular}{|l|c|c|c|c|c|}
\hline \multicolumn{7}{|c|}{ Month } & $\begin{array}{c}\text { Total productivity, } \\
\text { UAH }\end{array}$ & $\begin{array}{c}\text { Worked, } \\
\text { hours }\end{array}$ & $\begin{array}{c}\text { Marginal } \\
\text { productivity }\end{array}$ & $\begin{array}{c}\text { Wages are } \\
\text { calculated, UAH }\end{array}$ & $\begin{array}{c}\text { The marginal } \\
\text { cost of labour }\end{array}$ \\
\hline \multicolumn{7}{|c|}{ Seamstress № 1 } \\
\hline December 2017 & 43885 & 188.6 & - & 10895 & - \\
\hline January 2018 & 21307 & 87.9 & 224.21 & 4895 & 59.5829 \\
\hline February 2018 & 38165 & 164.7 & 219.51 & 9366 & 58.2161 \\
\hline March 2018 & 42813 & 185.4 & 224.54 & 10765 & 67.5845 \\
\hline April 2018 & 45213 & 197.3 & 201.68 & 11245 & 40.3361 \\
\hline
\end{tabular}

Source: developed by the authors

The analysis carried out in Table 2 shows that for a seamstress № 1, the monthly production load should not exceed 185.4 hours. The optimum load is in the range of $164.7 \mathrm{~h}$. per month, which will also ensure the optimization of labour costs. Using the results of the study will not only maximize labour productivity per one hour of labour but also create the necessary time reserve for proper relaxation and recuperation of workers at a given production site and increase labour productivity per one hour of labour. 

Cooperation Between Enterprises and State Institutions

The indicated recommendations can also be used during the organization and functioning of the industrial park, which was created based on Kherson Cotton Plant. At the same time, despite economic and investment expediency, taking into account political instability, the military situation in some regions of Ukraine introduced in November 2018, etc., foreign investors and credit institutions in many cases renounce such investments, arguing that this is a high level of riskiness and a very moderate level of profitability of attracted capital. This is also confirmed by the fact that as a result of an imperfect regulatory framework in recent years, raider attacks constantly occur in the Kherson region, the results of which have already destroyed several leading economically active industrial facilities. The improvement of the regulatory system also requires an effective mechanism for the protection of property not only for foreign investors but also for domestic business entities. This will reduce the outflow of domestic capital abroad and legalize business. Lack of effective state policy on the unshadowing of personal and corporate income reduces not only the volume of tax revenues to budgets of all levels, but also creates false information regarding the level of purchasing power of the population of Ukraine, restraining the attraction of foreign sources of funding for the organization and creation of a joint businesses for the production and sale of goods (services) on the territory of Ukraine. According to the research of Ministry of Economic Development and Trade of Ukraine (Ministry of economic development and trade of Ukraine, 2015) in 2014 , the shadow economy was about $41 \%$ of the official GDP or at least UAH 650 billion in 2014 figures. Even with a constant level, the shadow economy in the figures in 2017 would amount to about UAH 1223.0 billion. As a result, the State Budget of Ukraine did not receive at least UAH 220 billion in revenues. This is also the result of unfulfilled initiatives of state authorities on the urgent reduction of interest rates of value-added taxes up to $17 \%$ and on corporate profits up to $16 \%$, which facilitates the continuation of the use of "shadow" schemes for the sale and payment for manufactured products with the use of offshore zones and other mechanisms for evasion of payment of these taxes. Thus, tax rates in Cyprus are the most favourable for entrepreneurs who have deployed their activities in Ukraine. This is since in Cyprus the income tax on entrepreneurs is paid only when there is a profit. At the same time, the tax is only $12.5 \%$ of the profit, which is 5.5 percentage points lower than the legally established level in Ukraine. The valueadded tax is $15 \%$, which is 5 percentage points less than in Ukraine. The developing and sale of products through fictitious companies in Cyprus allows not only to reduce the tax burden while conducting business, but also to send the received money resources to the statute of a domestic enterprise in the form of foreign investments from the EU country, having obtained the support of the European community.

Considering the results of the conducted research, as well as the increase of the level of shadow economy in Ukraine, it would be interesting to implement the next set of measures to amnesty capital: the applicant - a legal entity and/or an individual - is required to pay at least $4.5 \%$ of the declared value of the property or purchase securities of domestic strategic enterprises for a sum of at least $15 \%$ of the value of the additional declared income. The specified amnesty of capital should last no more than 6 months and be a one-time deal. At the end of its term, it would be advisable to provide for a substantial increase in fines up to the confiscation of undeclared property. Received additional investment can be used in the development of strategic enterprises, for example, "Kherson Cotton Plant" (Kherson), and would allow to implement a developed investment project and ensure not only the payment of previously existing wage arrears but also create new jobs with decent wages.

Conclusions. The conducted studies indicate that the introduction of a sound methodological approach to assessing the level of socio-economic development of the country and regions in particular will allow not only to identify problem areas in the development of the respective territories, but also to get the potential investor reliable information about the real state of affairs and to determine the justification of further investment in the activity of the object of study. It was revealed that among the key areas of interaction is assistance from state and local authorities in obtaining additional economic privileges by economic entities of all forms of ownership through the creation of industrial parks in strategic areas of economic activity. 
N. Tyukhtenko, S. Makarenko, N. Oliinyk, K. Gluc, Ed. Portugal, S. Rybachok. Innovative Development of the Regions: Cooperation Between Enterprises and State Institutions

One of the most important factors in increasing the efficiency of production and maximizing the probability of attracting investments is to ensure the economic and rational use of material, labour, financial resources, production capacity; optimization of the structure of resource consumption based on the introduction of new design and technological solutions that allow to increase the completeness of the use of production resources; reducing the cost of productive resources at all stages of production and consumption. The results of the analysis and determination of the strengths and weaknesses, opportunities and threats of the economy of the Kherson region indicate the need to develop measures to ensure the economic security of the region. To solve these problems at the regional level, it is necessary to implement a state policy that would be implemented in such areas: provide reliable institutional protection of property rights of investors; improvement of the legislative framework; creation in Ukraine of an effective anti-corruption mechanism, the development of an effective state policy on amnesty and unshadowing of incomes of individuals and legal entities. The mechanism of determining the optimal predictive model, taking into account the influence of the shadow sector on the official statistical indicators of the development of the economy and the processing industry, in particular, deserves further study.

Author Contributions. Conceptualization, N.T., K.G. and P. Ed.; methodology, S.M.; software, S.M.; validation, N.T. and N.O.; formal analysis, N.O.; investigation, S.M.; resources, S.R; data curation, S.R.; writing-original draft preparation, S.M.; writing-review and editing, N.T. and S.R.; visualization, S.M.; supervision, N.O.; project administration, N.T.; funding acquisition, S.R.

Funding. This research was supported by the Kherson regional organization of the trade union of textile and light industry workers and the primary trade union organization of "Kherson Cotton Factory".

\section{References}

Adair, P., \& Adaskou, M. (2018). The capital structure of mature French SMEs and impact of the great recession: A dynamic panel data analysis (2002-2010). Economics, Management and Sustainability, 3(2), 60-75.

Allen, J. (2007). Third generation science parks. Manchester Science Park Ltd.

Bell, M., Pavitt, K. (1997). Technological accumulation and industrial growth: contrasts between developed and developing countries. W: D. Archibugi, J. Michie (red.). Technology, globalization and economic performance. Cambridge: Cambridge University Press.

Bilovodska, O. A. (2017). Marketing distributive and sales policy: research of essence, role and importance. Marketing and Manadgment of Innovations, vol. 2, pp. 85-97.

Bohdaniuk I., Kolisnichenko V., \& Ustymenko O. (2018). Audit as a form of control of the state financial inspection of Ukraine. Baltic Journal of Economic Studies. Vol. 4, no. 5, pp. 31-35.

Bruneel, J., Ratinho, T., Clarysse, B., Groen, A. (2012). The evolution of business incubators: Comparing demand and supply of business incubation services across different incubator generations, Technovation, 32 (2), pp. 110-121.

Burkynskyi, B. V., Lazareva, E. V., \& Aheeva, Y. N. (2002). Competitiveness of products and enterprises: monohrafyia. Odessa: Institute of market problems and economical ecological researches of the NAS of Ukraine.

Capello, R., Caragliu, A., \& Nijkamp, P. (2009). Territorial Capital and Regional Growth: Increasing Returns in Cognitive Knowledge Use. Tinbergen Institute Discussion Paper. TI 2009-059/3.

Cepel, M., Stasiukynas, A., Kotaskova, A., \& Dvorsky, J. (2018). Business Environment Quality Index in the SME Segment. Journal of Competitiveness, 10(1), pp. 21-40.

Customs Code of Ukraine: Code of Laws of Ukraine dated March 13, 2012 No. 4495-VI. Verkhovna Rada of Ukraine. Available at: https://zakon.rada.gov.ua/laws/show/4495-17/print.

Derkach, A. A., Zazykyn, V. H., \& Markova, A. K. (2000). Psychology of professional development: a textbook. Moscow: Nauka.

Economic Discussion Club (2018). The position of Ukraine in the world ranking according to the Global Competitiveness Index 2017-2018. Available at: http://edclub.com.ua/analityka/pozyciya-ukrayiny-v-reytyngu-krayin-svitu-za-indeksom-globalnoyikonkurentospromozhnosti-2.

Edquist, C. (2004). Systems of Innovation - A Critical Review of the State of the Art. W: J. Fagerberg, D. Mowery, R. Nelson (red.), Handbook of Innovation. Oxford: Oxford University Press.

Guziejewska, B. (2015). Designing a revenue structure in local self-government entities in Poland: taxes versus grants. Equilibrium. Quarterly Journal of Economics and Economic Policy. Vol. 10, no 3, pp. 45-63.

Ivanová, E., \& Cepel, M. (2018). The Impact of Innovation Performance on the Competitiveness of the Visegrad 4 Conutries. Journal of Competitiveness, 10(1), pp. 54-72. 
N. Tyukhtenko, S. Makarenko, N. Oliinyk, G. Krzysztof, Ed. Portugal, S. Rybachok. Innovative Development of the Regions: Cooperation Between Enterprises and State Institutions

Ključnikov, A., Kozubíková, L., \& Sopková, G. (2017). The Payment Discipline of Small and Medium-sized Enterprises. Journal of Competitiveness, 9(2), pp. 45- 61. https://doi.org/10.7441/joc.2017.02.04.

Klymenko, S. M., Dubrova, O. S., Barabas, D. O., Omelianenko, T. V., \& Vakulenko A.V. (2006). Management competitiveness of enterprise. Available at: http://posibniki.com.ua/catalog-upravlinnya-konkurentospromozhnistyu-pidpriemstva---klimenko-sm.

Ko, H., \& Min, K. (2019). Determinants of social expenditures in post-socialist countries. Economics and Sociology, 12(2), pp. 253-264. doi:10.14254/2071- 789X.2019/12-2/15.

Kozubikova, L., Kotaskova, A., Dvorsky, J., \& Kljucnikov, A. (2019). The impact of political factors' perception on suitability of international business environment: The case of startups. Economics and Sociology, 12(1), pp. 61-79.

Lozova, O. V. (2012). Forecasting of social and economic development as an instrument of state regulation of social processes in Ukraine. Bulletin of Donetsk National University of Economics and Trade. M. Tugan-Baranovsky. Series of Economic Sciences. vol. 4, no 56, pp. 28-36.

Lozovetska, V. T. (2015). Professional career of the individual in modern conditions: monograph. Kyiv: Institute of Vocational Education NAPS of Ukraine.

Maisiura, O. M. (2010). On the effectiveness of using personal time (to the issue of time management). Actual problems of economics, vol. 2, no 104, pp. 196-200.

Malai, A. O. (2011). Ways to improve the investment climate in Ukraine. Economy and the state. vol. 9, pp. 102-105.

Mas'ud, A., Manaf, N. A. A., \& Saad, N. (2019). Trust and power as predictors to tax compliance: Global evidence. Economics and Sociology, 12(2), pp. 192-204.

Monitoring of socio-economic development of regions of Ukraine for January-October 2018 (2018). Research Center for Industrial Development Problems of the National Academy of Sciences of Ukraine. Available at: https://ndc-ipr.org

North, D. (1991). Institutions. Journal of Economic Perspectives, 5(1), pp. 97-112.

Obadić, A., \& Aristovnik, A. (2011). Relative efficiency of higher education in Croatia and Slovenia: an international comparison. Amfiteatru Economic, 13(30), pp. 362-376.

On Amendments to Annexes 1 and 2 to the Procedure for Evaluation of the Results of the Activity of the Council of Ministers of the Autonomous Republic of Crimea, Kyiv region and Sevastopol City State Administrations: Resolution of the Cabinet of Ministers of Ukraine dated April 9, 2012 No. 335. Cabinet of Ministers of Ukraine. Available at: https://zakon.rada.gov.ua/laws/show/335-2012$\% \mathrm{DO} \% \mathrm{BF} \# \mathrm{n} 2$

On Amendments to Certain Legislative Acts of Ukraine in connection with the adoption of the Customs Code of Ukraine: Law of Ukraine dated March 13, 2012 No. 4496-VI. Verkhovna Rada of Ukraine. Available at: https://zakon.rada.gov.ua/laws/show/4496$17 /$ print.

On industrial parks: Law of Ukraine dated June 21, 2012 No. 5018-Vl. Verkhovna Rada of Ukraine. Available at: https://zakon.rada.gov.uallaws/show/5018-17/print.

On introduction of an evaluation of the results of the activity of the Council of Ministers of the Autonomous Republic of Crimea, Kyiv region and Sevastopol city state administrations: Resolution of the Cabinet of Ministers of Ukraine dated June 9, 2011 No. 650 Cabinet of Ministers of Ukraine. Available at: https://zakon.rada.gov.ua/laws/show/650-2011-\%D0\%BF.

On the collection and registration of a single contribution to the compulsory state social insurance: Law of Ukraine dated July 8, 2010 No. 2464-Vl. Verkhovna Rada of Ukraine. Available at: http://zakon3.rada.gov.ua/laws/show/246417/print1453111419053738

On the regime of foreign investment: Law of Ukraine of March 19, 1996, No. 93/96-VR. Verkhovna Rada of Ukraine. Available at: https://zakon.rada.gov.ua/laws/show/93/96-\%D0\%B2\%D1\%80/print.

Pavelková, D., Friedel, L., Jirčíková, E., Knápková, A., Skokan, K., \& Škodáková, P. (2009). Klastry a jejich vliv na výkonnost firem. Praha: Grada.

Soloviova, N. I., Makarenko, S. M., \& Oliynik, N. M. (2016). Methodological correctness of forecast estimation of the regional socioeconomic development parameters. Actual problems of economics, vol. 11, no 185, pp. 268-277.

State Statistics Service of Ukraine (2018). Economic activity of the population of Ukraine 2017: Statistical collection. Available at: http://ukrstat.gov.ua.

Trends in the shadow economy in Ukraine: the first quarter of 2015 (2015). Ministry of economic development and trade of Ukraine. K.

Tsymbaliuk, S. O. (2017). Determinants of personnel labor activity within the system of motivation. Actual problems of economics, vol. 1, no 187, pp. 264-272.

Tyukhtenko, N. A., \& Makarenko, S. M. (2016). Economic and mathematic models for staff planning at enterprises of all ownership forms. Actual problems of economics, vol. 1, no 175, pp. 435-442.

Veliu, L., Manxhari, M., Podvorica, N., Fejza, E., \& Hyesni, V. (2018). Managing SMEs in a turbulent context: A case study from a Kosovan manufacturing company. Journal of Competitiveness, 10(1), pp. 155-170.

Yaroshenko, I. V., \& Semyhulina, I. B. (2015). Methodological approaches to the creation and maintenance of a system of monitoring and evaluation of socio-economic development of regions in Ukraine. Problems of the Economy. vol. 1, pp. 180-186.

Zachosova, N. (2019) Innovative approach in the estimatology of financial institutions economic security: possibilities of use in management and regulatory activity within the means of provision of the state financial security. Baltic Journal of Economic Studies. Vol. 5, no. 2, pp. 45-56. 
N. Tyukhtenko, S. Makarenko, N. Oliinyk, K. Gluc, Ed. Portugal, S. Rybachok. Innovative Development of the Regions: Cooperation Between Enterprises and State Institutions

Н. А. Тюхтенко, к.е.н., професор, Херсонський державний університет (україна);

С. М. Макаренко, к.е.н., доцент, Херсонський державний університет (Україна);

Н. М. Олійник, к.е.н., доцент, Херсонський національний технічний університет (Україна);

K. Глуц, D.SC., доцент, Малопольська школа публічного управління, Краківський університет економіки (Польща);

E. Португал, Ph.D., професор, Державний університет штату Нью-Йорк в Потсдамі (США);

C. А. Рибачок, Херсонський державний університет (Україна).

Інноваційний розвиток регіонів: співпраця між підприємствами та державними установами. У $\mathrm{cmammi}$ виявлено, що в умовах обмеженості джерел фрінансування для впровадження передових інноваційних технологій та модернізації устаткування втримати наявні позиції та підвищити загальний рівень конкурентоспроможності зможе лише те підприємство, яке налагодить тісний взаємозв'язок із органами державної влади, місцевого самоврядування та профрспілковими організаціями з метою отримання можливих преферениій для розвитку в межах діючого нормативно-правого поля. Доведено, що запровадження обгрунтованого методичного підходу стосовно оцінювання рівня соціальноеекономічного розвитку країни і регіонів зокрема дозволить не лише виявити проблемні місия у розвитку відповідних територій, а й отримати потенційному інвесторові достовірну інформацію щодо реального стану справ та визначити обгрунтованість подальших капіталовкладень у діяльність об'єкта дослідження. Встановлено, що серед ключових напрямів взаємодії $\epsilon$ сприяння від органів державної влади та місцевого самоврядування в отриманні субєктами господарювання всіх форм власності додаткових пільट за рахунок створення індустріальних парків за стратегічними напрямами економічної діяльності. Обгрнутовано, що одним з найважливіших факторів підвищення ефективності виробництва та максимізації вірогідності залучення інвестицій є забезпечення економічного та раціонального використання матеріальних, трудових, фрінансових ресурсів, виробничих потужностей; оптимізація структури ресурсоспоживання на основі впровадження нових проектних, конструкторських і технологічних рішень, які дозволяють підвищити комплектність використання виробничих ресурсів; скорочення витрат виробничих ресурсів на всіх стадіях виробництва і споживання. Проведене дослідження щодо визначення сильних й слабких сторін, можливостей та загроз економіки Херсонської області свідчить про необхідність розробки заходів щодо забезпечення економічної безпеки області. Для вирішення цих проблем на рівні регіону запропоновано реалізовувати державну політику, яка здійснювалася б за такими напрямами: забезпечення надійного інституційного захисту майнових прав інвесторів; вдосконалення законодавчої бази; створення в Україні дієвого механізму протидії корупції, розроблення дієвої державної політики щодо амністії та детінізації доходів фрізичних та юридичних осіб.

Ключові слова: соціально-економічний розвиток, менеджмент, інновації, індустріальний парк, конкурентоспроможність, іноземні інвестиції, амністія капіталу.

Manuscript received: 05.02.2019

(c) The author(s) 2019. This article is published with open access at Sumy State University.

Marketing and Management of Innovations, 2019, Issue 3

http://mmi.fem.sumdu.edu.ua/en 